\title{
STUDI NUMERIK PENGARUH JUMLAH SALURAN KOLEKTOR SURYA BENTUK SEGITIGA DENGAN POLA ALIRAN ZIG-ZAG
}

\author{
Arrad Ghani Safitra' ${ }^{1)}$, Lohdy Diana ${ }^{2)}$, Fifi Hesty Sholihah ${ }^{3)}$, Agung Setya Herwanda ${ }^{4)}$ \\ 1,2,3,4 Program Studi Sistem Pembangkit Energi, Politeknik Elektronika Negeri Surabaya \\ Email: arradgs@ pens.ac.id ${ }^{1)}$ \\ Nomor Telp : +62 85647659956 \\ Asal Negara: Indonesia
}

\begin{abstract}
ABSTRAK
Kolektor surya terus mengalami perkembangan untuk menghasilkan kualitas udara panas dengan temperatur yang tinggi. Pada penelitian ini menganalisa pengaruh jumlah saluran kolektor surya bentuk segitiga dengan pola aliran zig-zag. Variasi yang digunakan antara lain 8, 7, dan 6 saluran. Tujuan dari penelitian ini adalah merupakan inovasi pada proses pemanasan udara di dalam kolektor bentuk segitiga dengan pola aliran zig-zag dapat memperbanyak dan memperpanjang proses penyerapan panas matahari oleh udara. Penelitian dilakukan secara numerik dengan metode komputasi fluida. Tahapan awal adalah melakukan pemodelan secara tiga dimensi dan melakukan proses meshing. Tahapan kedua menentukan kondisi batas dan melakukan simulasi dengan dan tahapan terakhir adalah mengambil hasil simulasi untuk dianalisa. Kondisi batas yang digunakan pada penelitian ini posisi masukkan merupakan velocity inlet dengan udara memiliki kecepatan sebesar 19,6 m/s dan temperatur $300 \mathrm{~K}$. Sisi luaran yaitu pressure outlet dan heat flux disisi bagian wall heating saluran sebesar $750 \mathrm{~W} / \mathrm{m}^{2}$. Parameter simulasi menggunakan RNG k- $\varepsilon$ viscous model dengan scheme SIMPLEC, momentum, dan turbulent kinetic energy menggunakan diskritisasi second-order upwind. Hasil penelitian menunjukkan kolektor segitiga dengan jumlah 7 saluran memiliki hasil dengan temperatur udara paling tinggi yaitu sebesar 41.86 K dan Bilangan Nusselt tertinggi sebesar 2.68.
\end{abstract}

Kata kunci: Kolektor surya, saluran, pola aliran, simulasi, temperatur.

\section{ABSTRACT}

Solar collectors are being upgraded all the time in order to produce high-quality hot air at high temperatures. This study analyzes the effect of the number of solar collector channels in a triangular shape with a zigzag flow pattern. The variations used include 8, 7, and 6 channels. The purpose of this research is to develop an innovation for heating air in a triangle collector with a zigzag flow pattern that can improve and extend the process of solar heat absorption by the air. The research was carried out numerically with the computational fluid method. The initial stage is to create three-dimensional modeling and perform the meshing process. The second stage is to determine the boundary conditions and running simulations with and the last stage is to analyze the simulation findings. The boundary conditions used in this study are the inlet velocity with the air having a speed of $19.6 \mathrm{~m} / \mathrm{s}$ and a temperature of $300 \mathrm{~K}$. The output side, namely the pressure outlet and the heat flux on the side of the wall heating channel, is $750 \mathrm{~W} / \mathrm{m}^{2}$. The simulation parameters use the RNG $k-\varepsilon$ viscous model with the SIMPLEC scheme, momentum, and turbulent kinetic energy using a second-order upwind discretization. The results showed that the triangular collector with 7 channels had the highest air temperature and Nusselt Number of $41.86 \mathrm{~K}$ and 2.68, respectively.

\section{Keywords: Solar collector, channel, airflow, simulation, temperature.}

\section{PENDAHULUAN}

Polusi lingkungan dan penurunan kesehatan manusia disebabkan karena penggunaan energi fosil yang berlebihan. Kebutuhan energi semakin banyak dengan meningkatnya perkembangan ekonomi dan teknologi. Hal ini menyebabkan permintaan energi dunia juga akan semakin meningkat. Energi matahari merupakan salah satu sumber energi terbarukan yang sangat berpotensi untuk digunakan dan dikembangkan (Bayrak, Oztop, \& Hepbasli, 2013).
Energi matahari paling mudah diperoleh dan sangat ekonomis karena tidak perlu membeli dan disediakan oleh alam hampir setiap hari jika dibandingkan dengan energi fosil yang lama kelamaan akan menipis dan habis (Devecioglu \& Oruc, 2017).

Oleh sebab itu, memanfaatkan lebih banyak energi matahari akan membantu mengurangi efek pemanasan global di bumi. Konversi matahari menjadi termal dari perangkat energi matahari merupakan faktor kunci tetapi untuk meningkatkan faktor konversi ini merupakan tantangan utama. 
Pemanas udara surya atau yang lebih dikenal dengan solar air heater (SAH) jenis plat datar konvensional telah banyak digunakan di seluruh dunia untuk konversi panas matahari. Faktor kunci untuk mengevaluasi kinerja SAH adalah efisiensi termalnya (Abdelkader et al., 2020).

Secara eksperimental mempelajari dan menganalisis pemanas udara cangkang ganda. Dalam penelitian mereka, efisiensi kolektor dioptimalkan secara menyeluruh (Ho, Chang, Lin, Chao, \& Tien, 2015).

Dalam penelitian yang dilaporkan oleh (Singh \& Dhiman, 2014) difokuskan pada penentuan kalor dan waktu yang berbeda. Suhu diukur sepanjang pukul 9.00 sampai 18.00, dan penelitian dilakukan pada pemanas udara surya alas batu. Hasilnya adalah penelitian ini mampu membuktikan bahwa penggunaan jenis air heater ini sangat tepat karena penyimpanan panasnya yang besar. Berbagai pemodelan matematis dilakkan olehnya dengan mempelajari kinerja termal berbagai jenis pemanas udara surya berdasarkan efek sirip dan baffle pada pemanas udara tenaga surya tipe laluan ganda.

Penelitian tentang kinerja sistem kolektor surya hibrida (pemanas air dan udara) dengan adanya radiasi yang stabil dan kurang stabil digabungkan dengan penggunaan PCM telah dilakukan. Hasilnya menunjukkan bahwa sistem tersebut memiliki efisiensi yang lebih tinggi di kondisi langit cerah dan laju aliran yang tinggi (Abed, 2016).

Beberapa penelitian tentang plat absorber dilakukan diantaranya oleh (Kumar, Bhagoria, \& Sarviya, 2009) yang melakukan penelitian secara eksperimental untuk mempelajari pengaruh plat absorber dan bahan penyimpanan panas laten secara bersamaan dalam pemanas udara surya konveksi paksa. Dibandingkan dengan plat absorber datar. Hasil mereka menunjukkan bahwa plat absorber pinfin yang dikemas dengan lilin paraffin memiliki penyimpanan panas tambahan untuk periode 3 jam dengan $2-5^{\circ} \mathrm{C}$ meningkatkan suhu udara keluar dan akibatnya thermo 3-35\% lebih tinggi. Efisiensi hidrolik dengan efisiensi eksergi 2- $15 \%$ lebih tinggi.

Dari metode lain yang diusulkan untuk meningkatkan kinerja sistem, satu bisa merujuk pada penggunaan media berpori di dalam absorber, yang berfungsi sebagai pendekatan untuk meningkatkan efisiensi pemanas udara surya. Baru baru ini dalam penelitiannya (Devecioglu \& Oruc, 2017) telah menyelidiki kinerja termal secara eksperimental dari pemanas udara surya dengan plat absorber berpori dan sekat untuk membangun jalur heliks. Hasilnya di klaim, bahwa skema ini menyebabkan lebih banyak penyerapan radiasi matahari dan lebih banyak disteibusi di lapisan batas termal. Hasilnya menunjukkan bahwa kawat berpori menghasilkan efisiensi termal yang lebih tinggi dari pemanas udara. Masih dengan metode yang sama, pengaruh saluran heliks ada kinerja pemanas surya juga diselidiki oleh (Heydari \& Mesgarpour, 2018) dengan uji eksperimental dan numerik, inovasi penelitian ini adalah merancang saluran penampang segitiga sedemikian rupa membentuk aliran heliks melalui pemanas udara. Hasilnya adalah koefisien perpindahan panas keseluruhan dan efisiensi termal setelah dihitung dengan data eksperimen dan numerik sama hanya selisih 3\%. Pemanas ini diperkirakan lebih tinggi $14.7 \%$ dari saluran sederhana dan $8.6 \%$ lebih tinggi dari saluran udara surya bersirip ganda dengan laju aliran massa yang sama. Sistem lain berbentuk spiral diteliti oleh (Jia, Liu, \& Wang, 2019) dengan memanfaatkan perbedaan suhu antara inlet dan outlet, pemanas udara surya spiral (SAH), efisiensi pengumpulan panas diklaim dapat lebih tinggi dengan suhu dinormalisasi menjadi $5.69 \mathrm{~W} / \mathrm{m}^{2} \mathrm{~K}$ dibandingkan SAH konvensional dan serpentin.

Berdasarkan penelitian-penelitian yang telah dilakukan penelitian ini menganalisa pengaruh jumlah saluran kolektor surya bentuk segitiga dengan pola aliran zig-zag. Variasi yang digunakan antara lain 8, 7, dan 6 saluran. Tujuan dari penelitian ini adalah merupakan inovasi pada proses pemanasan udara di dalam kolektor bentuk segitiga dengan pola aliran zig-zag dapat memperbanyak dan memperpanjang proses penyerapan panas matahari oleh udara. Penelitian dilakukan secara numerik dengan metode komputasi fluida dengan pemodelan tiga dimensi.

\section{METODE PENELITIAN}

Pada penelitian ini menggunakan persamaanpersamaan umum antara lain:

Persamaan kekekalan masa

1. $\frac{\partial p}{\partial t}+\nabla(\rho \vec{v})=s_{m}$

Persamaan kekekalan momentum

2. $\frac{\partial}{\partial t}(p \vec{v})+\nabla(\rho \vec{v} \vec{v})=-\vec{v} \mathrm{p}+\nabla(\overline{\bar{\tau}})+\rho g \vec{f}$

Persamaan kekekalan energy

3. $\frac{\partial}{\partial t}(\rho E)+\nabla[\vec{v}(\rho E+p)]=-\vec{v}\left(\sum_{j} \mathrm{~h}_{j} J_{j}\right)+S h$

4. Pada perpindahan panas konveksi dipresentasikan dengan Bilangan Nusselt atau disingkat $\mathrm{Nu}$ dapat dicari menggunakan rumus:

$$
\begin{aligned}
& \qquad \mathrm{Nu}=\frac{\boldsymbol{h} \boldsymbol{L}}{\boldsymbol{k}} \\
& \qquad \mathrm{Nu}=0.332(\mathrm{Re})^{1 / 2}(\mathrm{Pr})^{1 / 3} \\
& \mathrm{Re}=\text { Reynolds number } \\
& \mathrm{Pr}=\text { Prandtl } \\
& \mathrm{h}=\text { koefisien perpindahan panas } \\
& \mathrm{L}=\text { Panjang } \\
& \mathrm{k}=\text { konduktivitas termal }
\end{aligned}
$$




\subsection{Geometri Solar Air Heater}

Geometri kolektor berukuran Panjang 500 $\mathrm{mm}$ dengan lebar $480 \mathrm{~mm}$ material kolektor aluminium dengan ukuran $0.5 \mathrm{~mm}$ serta lapisan atas kolektor terdapat kaca ukuran Panjang $500 \mathrm{~mm}$ dengan lebar 480 dengan tebal $5 \mathrm{~mm}$.

Kolektor variasi 8 saluran gelap dan 7 saluran terang pada Gambar 1 (a) dengan spesifikasi saluran kolektor gelap berupa segitiga sama sisi dengan panjang sisi $60 \mathrm{~mm}$ serta saluran kolektor terang berupa segitiga sama sisi terbalik dengan panjang sisi $60 \mathrm{~mm}$. Kolektor variasi 7 saluran gelap dan 6 saluran terang pada Gambar 1 (b) dengan spesifikasi saluran kolektor gelap berupa segitiga sama sisi dengan panjang sisi $60 \mathrm{~mm}$ serta saluran kolektor terang berupa trapezium terbalik dengan panjang sisi sejajar bagian atas adalah $70 \mathrm{~mm}$ dan bagian bawah $10 \mathrm{~mm}$. Kolektor variasi 6 saluran gelap dan 5 saluran terang pada Gambar 1 (c) dengan spesifikasi saluran kolektor gelap berupa segitiga sama sisi dengan panjang sisi $60 \mathrm{~mm}$ serta saluran kolektor terang berupa trapezium terbalik dengan panjang sisi sejajar bagian atas adalah 84 $\mathrm{mm}$ dan bagian bawah $24 \mathrm{~mm}$.

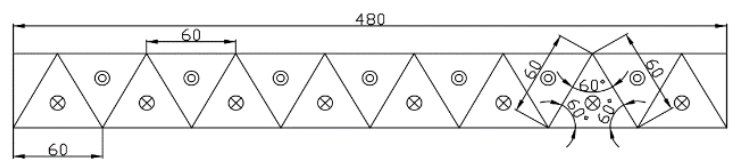

(a)

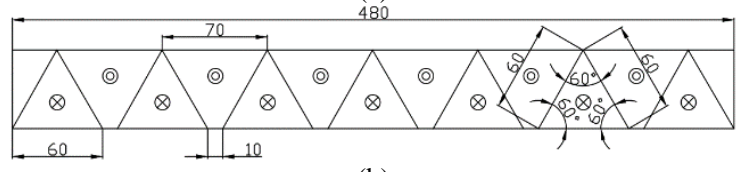

(b)

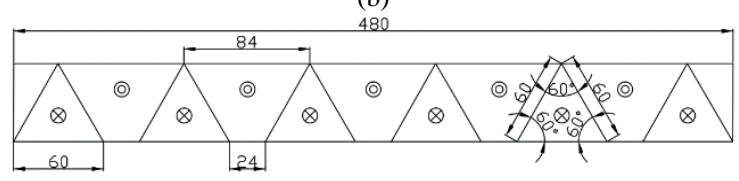

(c)

Gambar 1. Geometri penampang kolektor dengan (a) 8 saluran zig-zag, (b) 7 saluran zig-zag, dan (c) 6 saluran zigzag.

Tahapan awal simulasi adalah melalukan pemodelan secara tiga dimensi. Pemodelan yang dibuat dapat dilihat seperti pada Gambar 2.

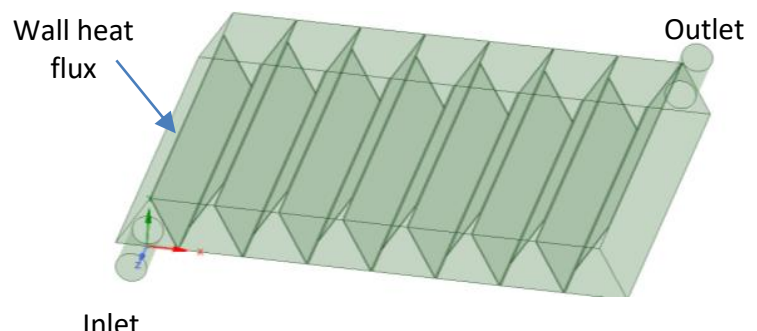

(a)

Outlet

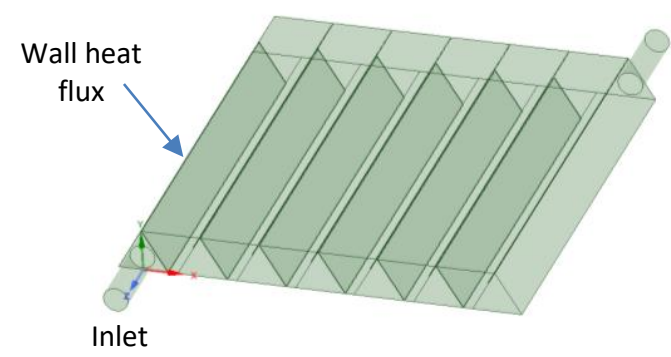

(b)

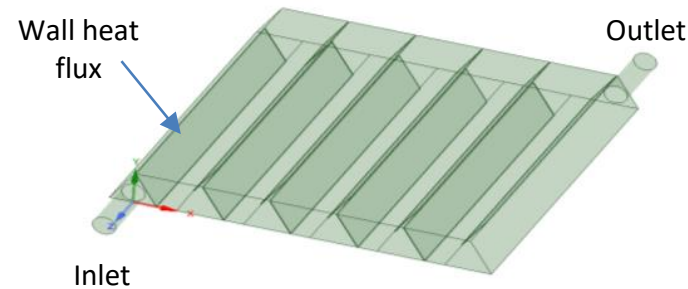

(c)

Gambar 2. Pemodelan geometri kolektor dengan (a) 8 saluran zig-zag, (b) 7 saluran zig-zag, dan (c) 6 saluran zigzag.

\subsection{Meshing}

Meshing yang digunakan adalah tetrahedral seperti ditunjukkan pada Gambar 3. Penelitian yang dilakukan oleh Ali S.Hussen, Balewgize Amare Zeru tentang Design, Optimization and CFD Simulation of Solar Air Heater with Jet Impingement on V-Corrugated Plate menggunakan meshing tetrahedral yang menghasilkan mesh yang cukup baik. Pemilihan tersebut dikarenakan mesh tetrahedral memiliki kemampuan adaptif terhadap bentuk-bentuk kurva atau bentuk yang tidak regular dan sudut yang kecil dapat di jangkau. Meshing pada ketiga geometri variasi kolektor dengan nilai element size yang berbeda beda mulai dari $0,02 \mathrm{~mm}$ sampai $0,003 \mathrm{~mm}$ dilakukan agar mendapatkan element size yang tepat dan akurat.

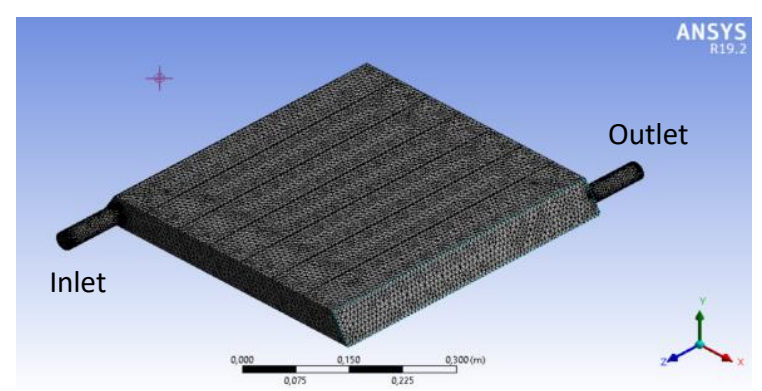

(a)

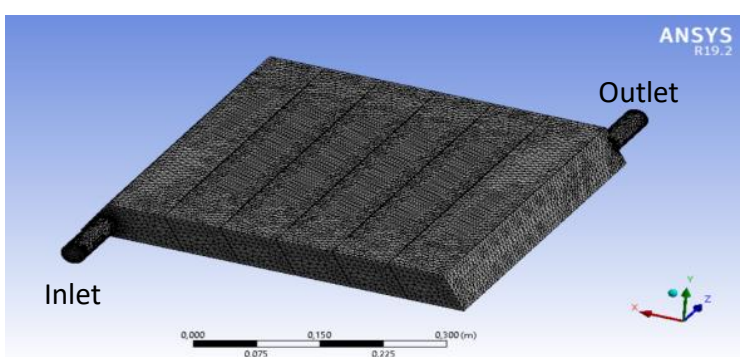

(b) 


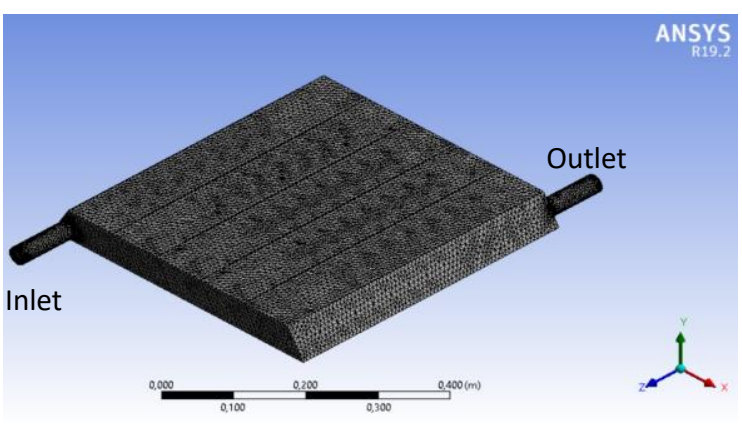

(c)

Gambar 3. Meshing pada kolektor dengan (a) 8 saluran zig-zag, (b) 7 saluran zig-zag, dan (c) 6 saluran zig-zag.

\subsection{Kondisi Batas}

Kondisi batas yang ditentukan untuk ketiga variasi kolektor antara lain adalah kecepatan pada sisi inlet sebesar $19,6 \mathrm{~m} / \mathrm{s}$ dengan temperatur inlet $300 \mathrm{~K}$. Sisi outlet yaitu pressure outlet dan heat flux di sisi bagian wall atas segitiga saluran gelap untuk Gambar 2 (a) dan sisi dalam bagian dasar saluran terang untuk Gambar 2 (b) dan Gambar 2 (c) saluran sebesar $750 \mathrm{~W} / \mathbf{m}^{2}$ serta wall bagian bawah terisolasi. Seperti yang ditunjukan pada Gambar 4.

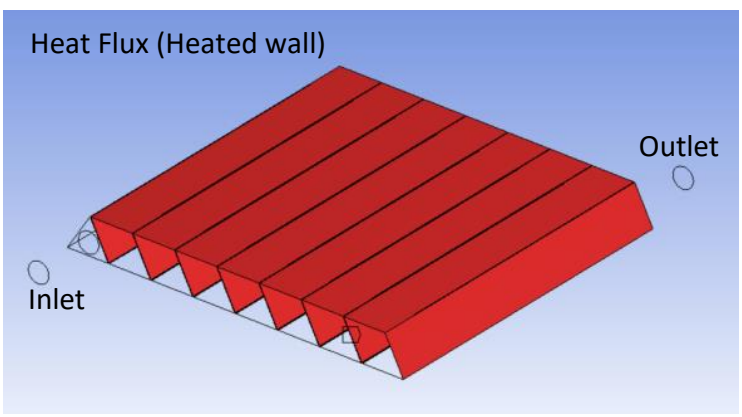

(a)

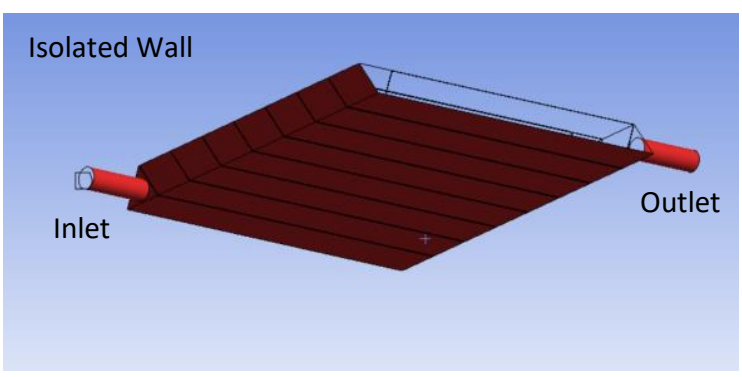

(a)

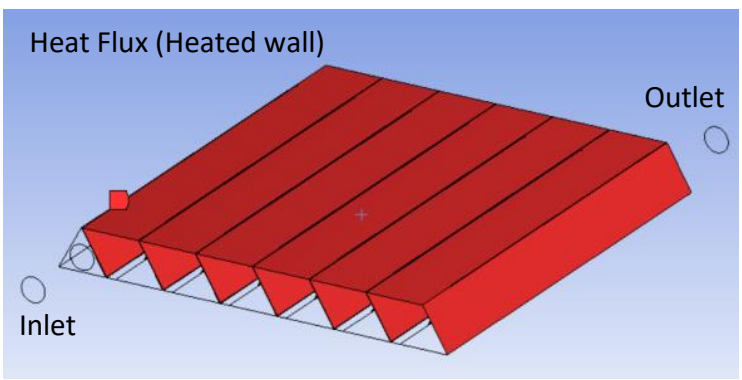

(b)

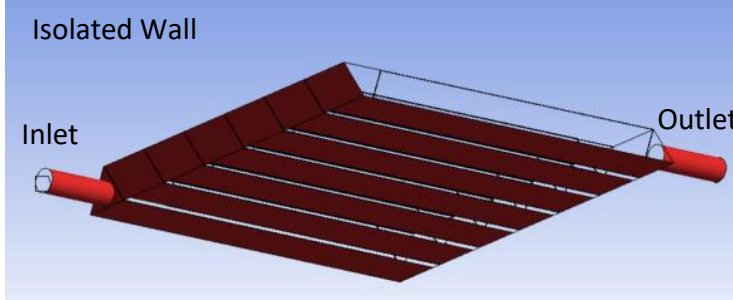

(b)

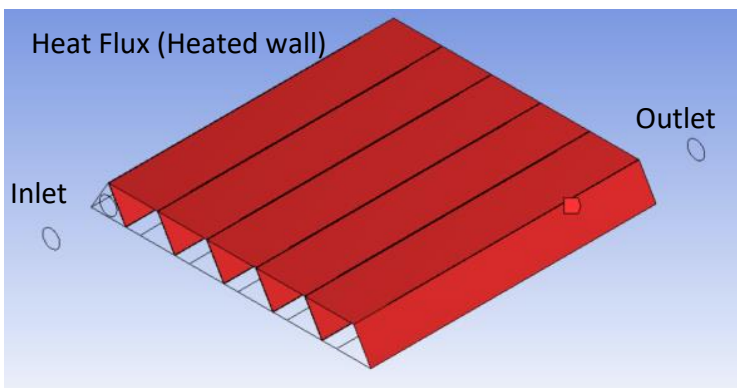

(c)

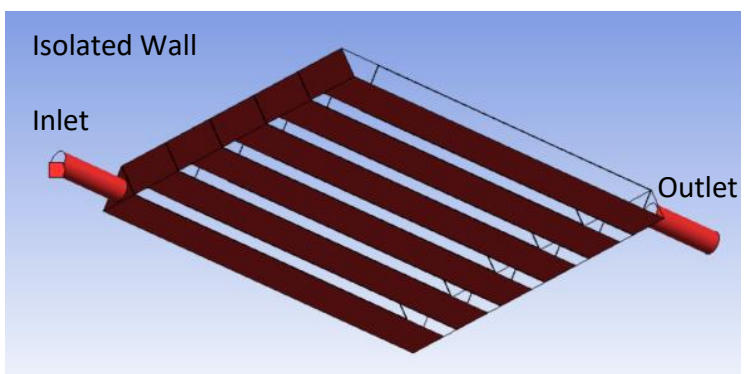

(c)

Gambar 4. Pemodelan geometri kolektor heat flux dan isolated wall dengan (a) 8 saluran zig-zag, (b) 7 saluran zigzag, dan (c) 6 saluran zig-zag.

\subsection{Parameter Setting}

Material yang digunakan adalah logam aluminium dan isolated wall dengan ketebalan 0,5 $\mathrm{mm}$. Pada simulasi kolektor boundary condition yang digunakan yaitu simulasi tiga dimensi dengan parameter model energy on, RNG k- $\varepsilon$ viscous model dan solution methods menggunakan scheme SIMPLEC, momentum second order upwind, turbulent kinetic energy second order upwind, kriteria konvergensi pada tingkat akurasi $\mathbf{1 0}^{-4}$ untuk residual kecepatan, momentum dan energi.

\section{HASIL DAN PEMBAHASAN}

3.1. Grid Independent

Grid independent dilakukan untuk menentukan nilai element size yang terbaik dan mempunyai nilai error mesh yang paling kecil. Pada simulasi ini grid independent yang digunakan menggunakan nilai element size sebesar 0,005 yang mempuyai nilai error paling terkecil yang di tujukan pada Gambar 5. 


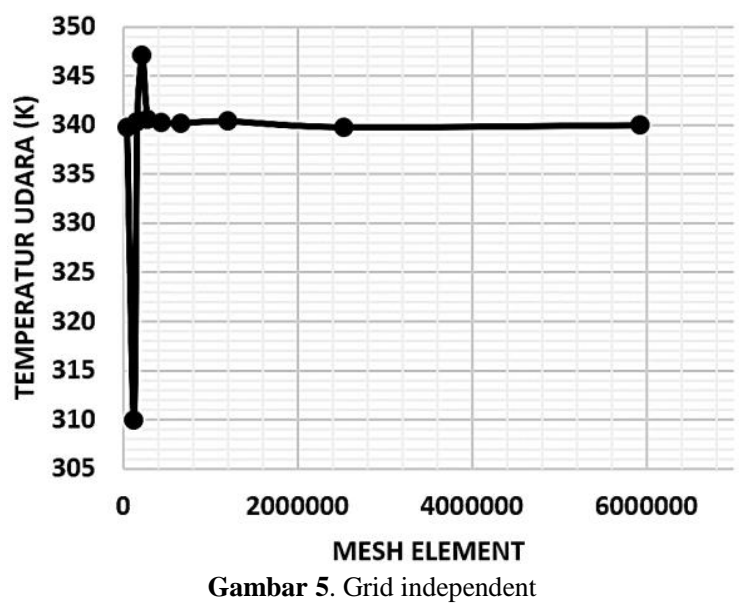

\subsection{Peningkatan Temperatur Udara}

Berdasarkan Tabel 1 menunjukkan kolektor surya segitiga dengan jumlah 7 saluran memiliki temperatur keluar tertinggi dengan peningkatan temperatur udara sebesar $41.86 \mathrm{~K}$ dan kolektor surya segitiga dengan jumlah 6 saluran memiliki peningkatan temperatur udara terendah yaitu sebesar $38.17 \mathrm{~K}$

Tabel 1. Perbandingan temperatur udara pada saluran kolektor

\begin{tabular}{ccc}
\hline Jumlah saluran & Masuk (K) & Keluar (K) \\
\hline 8 & 300 & 340.27 \\
7 & 300 & 341.86 \\
6 & 300 & 338.17 \\
\hline
\end{tabular}

\subsection{Kontur Temperatur Udara Pada Bidang XZ}

Gambar 6 menunjukkan kontur temperatur udara pada bidang $\mathrm{Z}$ dengan pola yang tidak merata.

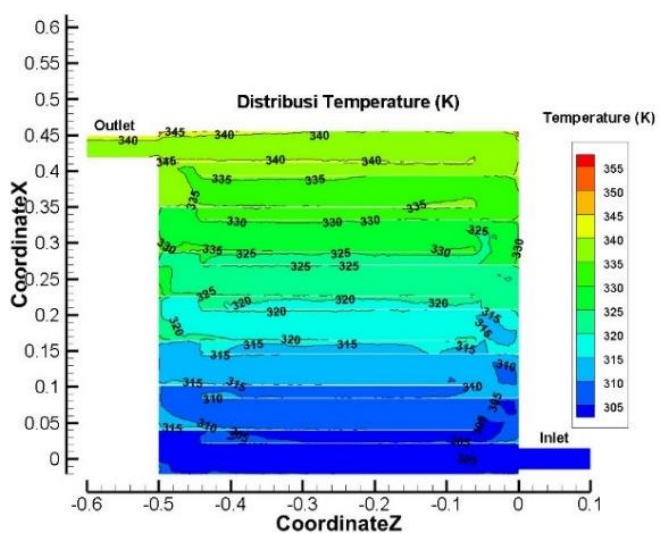

(a)

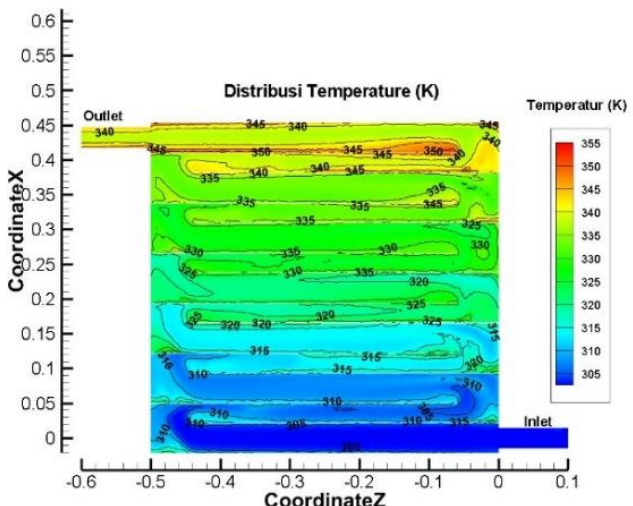

(b)

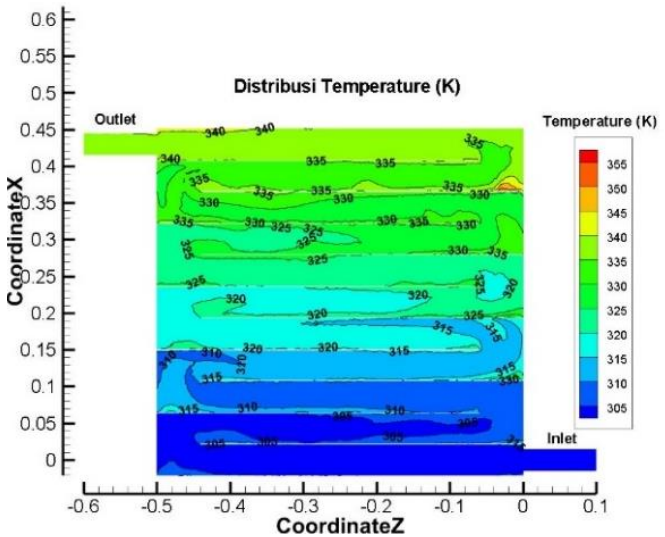

(c)

Gambar 6. Kontur Temperatur Udara Pada Bidang XZ dengan (a) 8 saluran zig-zag, (b) 7 saluran zig-zag, dan (c) 6 saluran zig-zag.

Dengan ketentuan kontur warna sebagai berikut warna biru menunjukan temperatur inlet udara serta warna hijau dan orange menunjukan temperatur udara yang melewati kolektor menuju outlet. Berdasarkan Gambar 6 distribusi temperatur udara pada kolektor dengan 7 saluran memiliki area udara dingin lebih sedikit jika dibandingkan dengan kolektor dengan jumlah saluran 8 , dan 6. Hal tersebut terjadi pada koordinat $\mathrm{X}=0.15 \mathrm{~m}$. Sedangkan kolektor dengan jumah saluran 6 masih memiliki area biru dan hijau yang cukup banyak hingga $X=0.4 \mathrm{~m}$. Sedangkan kolektor dengan jumlah saluran 8 memiliki kontur temperatur udara yang berada di tengah dimana saat $\mathrm{X}=0.4 \mathrm{~m}$ nilai temperatur udara masih lebih kecil jika dibandingkan dengan jumlah 7 saluran. Hal tersebut dimungkinkan terjadi gesekan antara udara panas dengan dinding kolektor sehingga terjadi kehilangan panas. Berdasarkan kontur temperatur udara yang telah diperoleh menandakan kolektor dengan saluran 7 merupakan jumlah saluran yang paling optimum dimana udara mengalami proses pemanasan yang cukup lama.

\subsection{Bilangan Nusselt}

Bilangan Nusselt merupakan rasio perpindahan panas konveksi dan konduksi normal terhadap batas pada permukaan fluida. Berdasarkan 
Tabel 3 diperoleh nilai Bilangan Nusselt untuk kolektor dengan jumlah saluran 7 memiliki nilai paling tinggi jika dibandingkan dengan jumlah saluran 6 dan 8. Hal tersebut menandakan kolektor dengan jumlah saluran 7 memiliki perpindahan panas yang paling baik. Hal tersebut dikarenakan terjadi perbandingan lurus antara Bilangan Nusselt dengan perpindahan panas.

\begin{tabular}{cc}
\multicolumn{2}{c}{ Tabel 2. Bilangan Nusselt udara pada kolektor } \\
\hline Jumlah saluran & $\mathrm{Nu}$ \\
\hline 8 & 2.44 \\
7 & 2.68 \\
6 & 2.39 \\
\hline
\end{tabular}

\subsection{Kontur Tekanan Udara Pada Bidang XZ}

Gambar 7 menunjukkan kontur tekanan udara pada bidang Z. Berdasarkan Gambar 6 distribusi tekanan udara pada kolektor memiliki nilai yang tinggi saat di sisi masukkan dan terus mengalami penurunan hingga udara menuju di sisi luaran. Hal tersebut terjadi pada semua jumlah saluran ditandai dari warna merah hingga $\mathrm{X}=0.05$ $\mathrm{m}$.

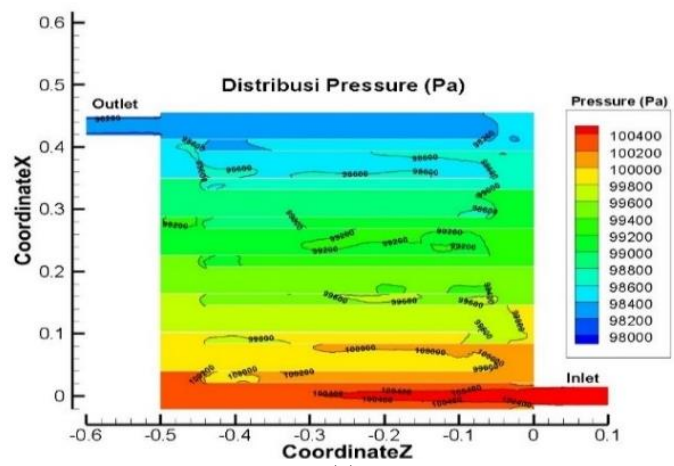

(a)

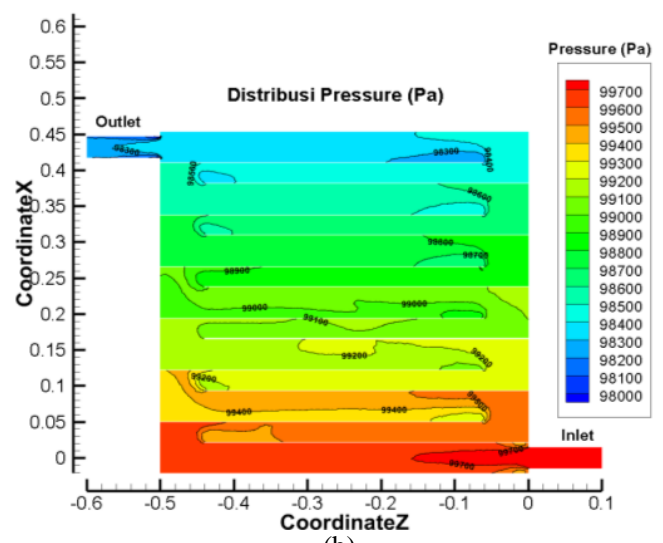

(b)

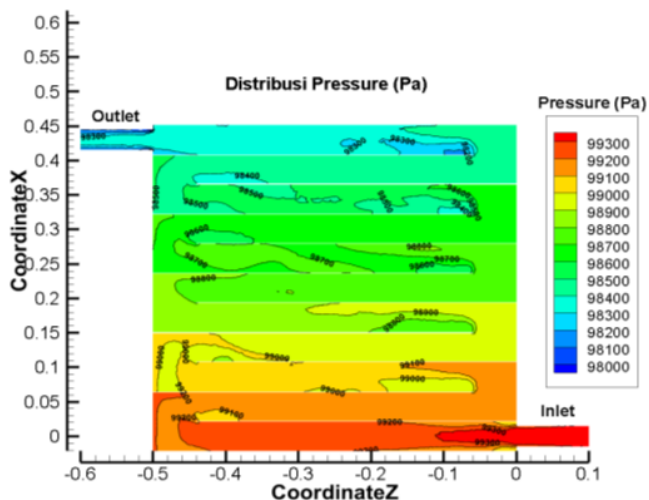

(c)

Gambar 7. Kontur Tekanan Udara Pada Bidang XZ dengan (a) 8 saluran zig-zag, (b) 7 saluran zig-zag, dan (c) 6 saluran zig-zag.

Berdasarkan nilai pada Gambar 7(a), kolektor dengan jumlah saluran 8 memiliki penurunan tekanan sebesar 99097.94 Pa. Berdasarkan nilai pada Gambar 7(b), kolektor dengan jumlah saluran 7 memiliki penurunan tekanan sebesar 98755.77 Pa, kolektor dengan jumlah saluran 7 memiliki penurunan tekanan sebesar 98555.04 Pa ditunjukkan pada Gambar 7(c). Dari hasil tersebut dapat disimpulkan bahwa jumlah saluran berpengaruh terhadap penurunan tekanan udara. Kolektor dengan jumlah saluran 6 memiliki penurunan tekanan paling kecil jika di bandingkan dengan jumlah saluran 7 dan saluran 8 .

\subsection{Pola Aliran Udara Pada Bidang XZ}

Gambar 8 menunjukkan pola aliran udara yang terjadi di dalam saluran pada bidang XZ. Gambar 8(a) menunjukkan pola aliran udara pada kolektor jumlah 8 saluran dengan relatif lurus olakan yang terbentuk hanya terjadi di ujung laluan namun dengan bentuk yang tidak terlalu besar. Hal tersebut dapat dikarenakan ukuran saluran yang terlalu sempit jika dibandingkan dengan jumlah dua saluran yang lain. Gambar 8(b) menunjukkan pola aliran udara pada kolektor dengan jumlah 7 saluran, terjadi olakan yang terlihat jelas dengan ukuran yang besar pada ujung laluan dan olakan udara juga terjadi pada bagian sepertiga dekat dengan sisi masukkan. 


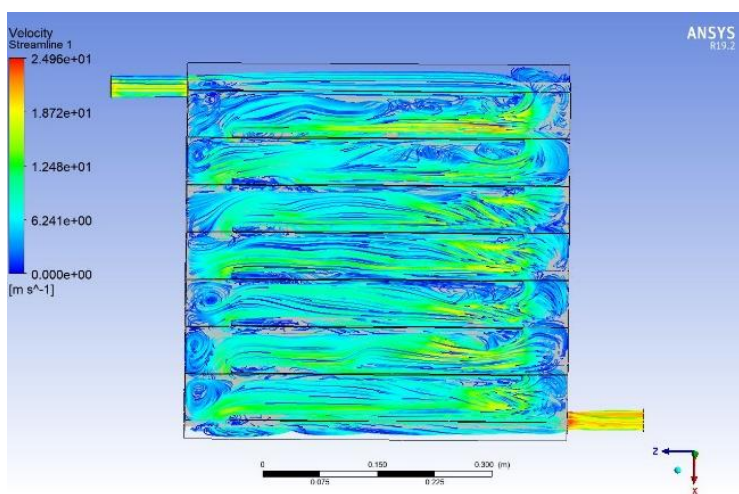

(a)

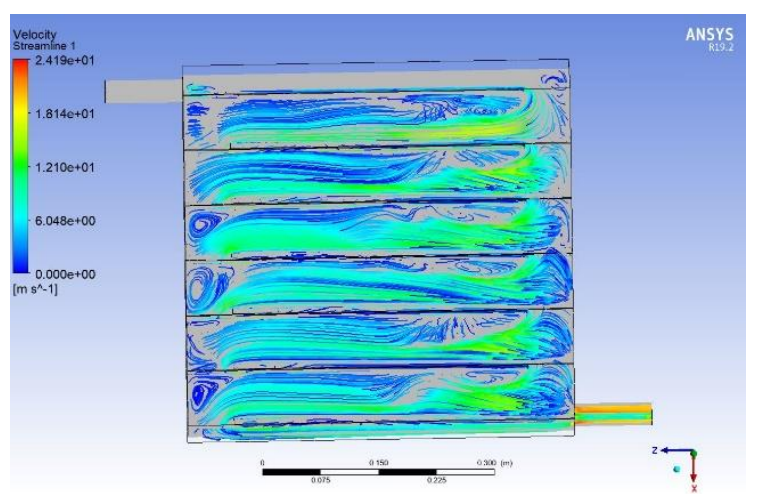

(b)

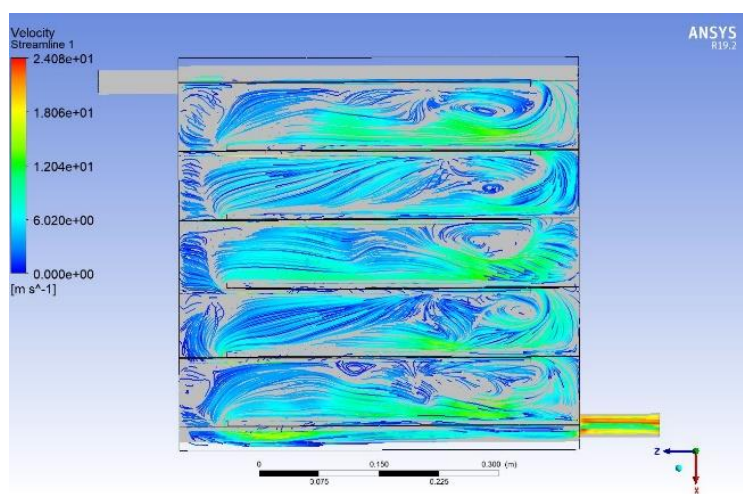

(c)

Gambar 8. Pola aliran Udara Pada Bidang XZ dengan (a) 8 saluran zig-zag, (b) 7 saluran zig-zag, dan (c) 6 saluran zig-zag.

\section{KESIMPULAN DAN SARAN}

Berdasarkan hasil penelitian yang telah dilakukan dapat disimpulkan bahwa:

1. Kolektor dengan jumlah 7 saluran memiliki peningkatan temperatur udara tertinggi yaitu sebesar $41.86 \mathrm{~K}$.

2. Kolektor dengan jumlah 7 saluran memiliki nilai Bilangan Nusslet tertinggi yaitu sebesar 2.68 .

3. Kolektor dengan jumlah 6 saluran memiliki nilai penurunan tekanan terendah yaitu sebesar 98555.04 Pa.

\section{UCAPAN TERIMA KASIH}

Ucapan Terima Kasih diberikan kepada Politeknik Elektronika Negeri Surabaya atas bantuan dana penelitian lokal pada tahun 2021, dan kepada Program Studi Sistem Pembangkit Energi, dan Laboratorium Termal.

\section{DAFTAR PUSTAKA}

Abdelkader, T. K., Zhang, Y., Gaballah, E. S., Wang, S., Wan, Q., \& Fan, Q. (2020). Energy and exergy analysis of a flat-plate solar air heater coated with carbon nanotubes and cupric oxide nanoparticles embedded in black paint. Journal of Cleaner Production, 250, 119501.

https://doi.org/10.1016/j.jclepro.2019.119501

Abed, A. H. (2016). Thermal Storage Efficiency Enhancement for Solar Air Heater Using a Combined SHS. 34(5), 999-1011.

Bayrak, F., Oztop, H. F., \& Hepbasli, A. (2013). Energy and exergy analyses of porous baffles inserted solar air heaters for building applications. Energy and Buildings, 57, 338345. https://doi.org/10.1016/j.enbuild.2012.10.055

Devecioglu, A. G., \& Oruc, V. (2017). Experimental Investigation of Thermal Performance of a New Solar Air Collector with Porous Surface. Energy Procedia, 113, 251-258. https://doi.org/10.1016/j.egypro.2017.04.062

Heydari, A., \& Mesgarpour, M. (2018). Experimental analysis and numerical modeling of solar air heater with helical flow path. Solar Energy, 162(January), 278-288. https://doi.org/10.1016/j.solener.2018.01.030

Ho, C. D., Chang, H., Lin, C. S., Chao, C. C., \& Tien, Y. E. (2015). Analytical and Experimental Studies of Wire Mesh Packed Double-pass Solar Air Heaters under Recycling Operation. Energy Procedia, 75, 403-409. https://doi.org/10.1016/j.egypro.2015.07.404

Jia, B., Liu, F., \& Wang, D. (2019). Experimental study on the performance of spiral solar air heater. Solar Energy, 182(September 2018), 16-21.

https://doi.org/10.1016/j.solener.2019.02.033

Kumar, A., Bhagoria, J. L., \& Sarviya, R. M. (2009). Heat transfer and friction correlations for artificially roughened solar air heater duct with discrete W-shaped ribs. Energy Conversion and Management, 50(8), 21062117.

https://doi.org/10.1016/j.enconman.2009.01.0 25

Singh, S., \& Dhiman, P. (2014). Thermal and thermohydraulic performance evaluation of a novel type double pass packed bed solar air heater under external recycle using an analytical and RSM (response surface 
methodology) combined approach. Energy, 72 , 344-359. https://doi.org/10.1016/j.energy.2014.05.044 